\title{
Isoprenoid Quinones in the Classification of Coryneform and Related Bacteria
}

\author{
By M. D. COLLINS* AND M. GOODFELLOW \\ Department of Microbiology, The University, Newcastle upon Tyne NE1 7RU \\ AND D. E. MINNIKIN \\ Department of Organic Chemistry, The University, \\ Newcastle upon Tyne NE1 $7 R U$
}

(Received 7 July 1978)

\begin{abstract}
Menaquinones were the only isoprenoid quinones found in 85 of the 95 coryneform bacteria examined. Dihydromenaquinones having nine isoprene units were the main components isolated from Corynebacterium bovis, from other glutamic acid-producing strains, and from Arthrobacter globiformis and related species. Dihydromenaquinones with eight isoprene units were found in Brevibacterium linens, the remaining Corynebacterium species and strains probably belonging to the genus Rhodococcus. Tetrahydromenaquinones with eight isoprene units were found in Arthrobacter simplex and Arthrobacter tumescens, and with nine isoprene units in Cellulomonas and Oerskovia. Kurthia and Curtobacterium were characterized by menaquinones with seven and nine isoprene units, respectively, and Microbacterium lacticum and Corynebacterium aquaticum had comparable amounts of menaquinones with 10 and 11 isoprene units. Strains received as Brevibacterium leucinophagum, Corynebacterium autotrophicum, Corynebacterium nephridii, Mycobacterium flavum, Mycoplana rubra and Protaminobacter ruber contained ubiquinones as their sole isoprenoid quinones. The isoprenoid quinone data correlate well with major trends in coryneform taxonomy and are of value in the classification of coryneform and related bacteria.
\end{abstract}

\section{INTRODUCTION}

In the current edition of Bergey's Manual of Determinative Bacteriology (Rogosa et al., 1974), the coryneform group of bacteria accommodates the genera Arthrobacter, Cellulomonas, Corynebacterium and, tentatively, Kurthia, with Brevibacterium and Microbacterium described as genera incertae sedis. The genus Curtobacterium (Yamada \& Komagata, 1972) proposed for certain 'motile brevibacteria' and the plant pathogens Corynebacterium flaccumfaciens and Corynebacterium poinsettiae should also be added to the coryneform group.

Improvements in the classification of coryneform and related bacteria have mainly been due to numerical phenetic studies (e.g. Bousfield, 1972; Jones, 1975), DNA base composition determinations (e.g. Bousfield, 1972; Skyring \& Quadling, 1970; Yamada \& Komagata, 1970 b; Bowie et al., 1972; Crombach, 1972; Starr et al., 1975), wall analyses (e.g. Schleifer \& Kandler, 1972; Keddie et al., 1966; Yamada \& Komagata, 1970 a, 1972; Keddie \& Cure, 1977) and mycolic acid analyses (Goodfellow et al., 1976; Alshamaony et al., 1976; Keddie $\&$ Cure, 1977). Preliminary data also suggest that isoprenoid quinone analyses may provide

* Present address: Department of Microbiology, The University, University Road, Leicester LE1 7RH. 
1<smiles>CC=CCC1=C(C)C(=O)c2ccccc2C1=O</smiles>

Menaquinone- $n$ $(\mathrm{MK}-m)$<smiles>CC=CCC1=C(C)C(=O)C(OC)=C(OC)C1=O</smiles>

Ubiquinone-n (Q-n)

good characters for the classification of coryneform and related taxa (Yamada et al., 1976; Collins et al., 1977).

Isoprenoid quinones are widely distributed in bacteria and two major structural groups can be recognized, menaquinones (vitamins K) (I) and ubiquinones (coenzymes Q) (II). Menaquinones, 2-methyl-3-polyprenyl-1,4-naphthoquinones, display structural variations which may include the length and degree of hydrogenation of the polyprenyl side-chain, hydroxylation (Allen et al., 1967) and possibly epoxidation (Friis et al., 1967). Ubiquinones, 2,3-dimethoxy-5-methyl-6-polyprenyl-1,4-benzoquinones, also show variations in the length and degree of saturation of the side-chain (Thomson, 1971).

Coryneform and related bacteria can be divided into several groups on the basis of menaquinone composition (Yamada et al., 1976; Collins et al., 1977). Thus, while human and animal parasitic corynebacteria contain predominantly dihydromenaquinones with eight isoprene units, abbreviated as MK- $8\left(\mathrm{H}_{2}\right)$ (see Biochemical Journal, 1975, 147, 15-2l for standard nomenclature and abbreviations), Corynebacterium bovis, Corynebacterium glutamicum and Mycobacterium strains have dihydromenaquinones with nine isoprene units, MK- $9\left(\mathrm{H}_{2}\right)$, as major components (Beau et al., 1966; Yamada et al., 1976; Collins et al., 1977). Tetrahydromenaquinones with eight isoprene units have been found in Nocardia and Arthrobacter simplex strains (Yamada et al., 1976; Collins et al., 1977) whereas MK-9 $\left(\mathrm{H}_{4}\right)$ has been reported in strains of Cellulomonas (Yamada et al., 1976), Oerskovia (Collins et al., 1977) and Propionibacterium (Schwartz, 1973; Sone, 1974).

This report presents the results of the mass spectral analysis of isoprenoid quinones from isolates bearing the labels Arthrobacter, Brevibacterium, Cellulomonas, Corynebacterium, Curtobacterium, Kurthia, Microbacterium, Mycobacterium, Mycoplana, Nocardia, Oerskovia and Protaminobacter.

\section{METHODS}

Cultures. The test strains (Table 1) were maintained on nutrient agar (Oxoid), and on Dorset Egg and Loeffler serum slopes (Cowan, 1974) at room temperature.

Cultivation. Strains were grown in shake flasks of nutrient broth [containing (per litre) $10 \mathrm{~g}$ peptone L34 (Oxoid), $8 \mathrm{~g} \mathrm{Lab} \mathrm{Lemco} \mathrm{L29} \mathrm{(Oxoid)} \mathrm{and} 5 \mathrm{~g} \mathrm{NaCl}$, pH 7.4] for $3 \mathrm{~d}$ at $30^{\circ} \mathrm{C}$. Cultures were checked for purity, killed with formaldehyde $(1 \%, v / v)$, harvested by centrifugation, washed with distilled water and freeze-dried.

Extraction and purification of isoprenoid quinones. Dried organisms were examined by the method of Collins et al. (1977).

Mass spectrometrv. Mass spectra of the purified isoprenoid quinones were recorded on an AEI MS9 instrument using a direct insertion probe, an ionizing voltage of $70 \mathrm{eV}$ and a temperature range of 190 to $220^{\circ} \mathrm{C}$.

Partial mass spectra of the isoprenoid quinones of all the strains listed in Table 1 have been deposited with the British Library Lending Division, Boston Spa, Yorkshire LS23 7BQ, as Supplementary Publication No. SUP 28009 (27 pages). Copies may be obtained from the BLLD on demand. Where possible, requests should be accompanied by prepaid coupons (held by many university and technical libraries and by the British Council). 
Table 1. Designation and source of test strains

\begin{tabular}{|c|c|c|c|c|c|}
\hline Taxon & No. & $\begin{array}{c}\text { Strain designation/ } \\
\text { source } f^{\text {t }}\end{array}$ & Taxon & No. & $\begin{array}{l}\text { Strain designation/ } \\
\text { source } \dagger\end{array}$ \\
\hline Arthrobacter albidus & 1 & *D6 (NCIB 10266) & C. fascians & 1 & Cl04 (NCPPB 1488) \\
\hline A. crystallopoietes & 1 & C218 (NCIB 9499) & C. flaccumfaciens & 1 & C9 (NCPPB 559) \\
\hline A. globiformis & 1 & ${ }^{*} \mathrm{~N} 549$ (NCIB 8907$)$ & C. herculis & 1 & *C85 (NCIB 9694) \\
\hline A. polychromogenes & 1 & C219 (NCIB 10267) & C. hoagii & 1 & C24 (NCTC 10673) \\
\hline A. roseoparaffinus & 1 & $\mathrm{C} 112(\mathrm{NCIB} 10700)$ & C. hydrocarboclastus & 2 & *D8, D9 (K. Komagata, \\
\hline A. simplex & 2 & $\begin{array}{l}\left.{ }^{*} \text { N295(NCIB } 8929\right) ; \mathrm{C} 272 \\
\text { (D. Jones, University of } \\
\text { Leicester; C120) }\end{array}$ & & & $\begin{array}{l}\text { Ajinomoto Co., Kawa- } \\
\text { saki, Japan; AJ 1386, } \\
\text { AJ 1379) }\end{array}$ \\
\hline A. tumescens & 1 & $\mathrm{C} 273(\mathrm{NCIB} 8914)$ & C. lilium & 1 & Cl 33 (NCIB 10337) \\
\hline A. ureafaciens & 1 & $\mathrm{C} 220(\mathrm{NCIB} 7811)$ & C. manihot & 1 & ${ }^{*} \mathrm{Cl} 34(\mathrm{NCIB} 9097)$ \\
\hline A. variabilis & 1 & D2 (NCIB 9455) & C. melassecola & I & $\mathrm{Cl} 36(\mathrm{NCIB} 10336)$ \\
\hline $\begin{array}{l}\text { Brevibacterium } \\
\text { ammoniagenes }\end{array}$ & 1 & C80 (NCIB 8143) & $\begin{array}{l}\text { C. minutissimum } \\
\text { C. murium }\end{array}$ & $\begin{array}{l}1 \\
1\end{array}$ & $\begin{array}{c}\left.{ }^{*} \text { D24 (NCTC } 10288\right) \\
\text { C60 (NCTC } 3655)\end{array}$ \\
\hline B. divaricatum & 1 & D3 (NCIB 9379) & C. mycetoides & 1 & C63 (NCTC 9864) \\
\hline B. fermentans & 1 & ${ }^{*} \mathrm{Cl} 22(\mathrm{NCIB} 9943)$ & C. nebraskense & 2 & H11, H12 (A. Vidaver, \\
\hline B. flavum & 1 & $\mathrm{C} 81$ (NCIB 9565) & & & University of Nebraska, \\
\hline B. immariophilum & 1 & C123 (NCIB 9544) & & & U.S.A.; Fur 1, Bennet \\
\hline B. lactofermentum & 1 & C124 (NCIB 9567) & & & Goth). \\
\hline B. leucinophagum & 1 & C125 (NCIB 9542) & C. nephridii & 1 & ${ }^{*} \mathrm{C} 264$ (DSM 20150) \\
\hline B. linens & 1 & ${ }^{*} \mathrm{C} 83(\mathrm{NCIB} 9909)$ & C. poinsettiae & 1 & C11 (NCPPB 844) \\
\hline B. paraffinolyticum & 1 & C113 (NCIB 1160) & C. pseudo- & 1 & $\mathrm{Cl9}($ NCTC 231$)$ \\
\hline B. roseum & 1 & $\mathrm{C} 82(\mathrm{NClB} 9564)$ & diphtheriticum & & \\
\hline B. saccharolyticum & 1 & $\mathrm{Cl} 27$ (NCIB 9543) & C. renale & 3 & HI, н2, н4 (R. Yanagawa, \\
\hline B. stationis & 1 & ${ }^{*}$ C41 (ATCC 14403) & & & Hokkaido University, \\
\hline B. sterolicum & 1 & $\mathrm{C} 188(\mathrm{NCIB} 11161)$ & & & Sapporo, Japan; 43, 45, \\
\hline B. sulfureum & 1 & C79 (NCIB 10355) & & & 42) \\
\hline Cellulomonas biazotea & $a 1$ & ${ }^{*} \mathrm{C} 221(\mathrm{NCIB} 8077)$ & C. rubrum & 1 & $\mathrm{Cl} 90(\mathrm{NClB} 9433)$ \\
\hline Cell. cartalyticum & 1 & C266 (DSM 20106) & C. xerosis & 1 & $\mathrm{Cl} 37$ (NCIB 9956$)$ \\
\hline Cell. fimi & 1 & $\mathrm{C} 274$ (NCTC 7547$)$ & Curtobacterium & 1 & ${ }^{*} \mathrm{C} 93$ ( NCIB 10702$)$ \\
\hline Cell. flavigena & 1 & ${ }^{*} \mathrm{C} 111(\mathrm{NClB} 8073)$ & citreum & & \\
\hline Cell. subalbus & 1 & C222( $\mathrm{NCIB} 8075)$ & Curtobacterium & 1 & *C94 (NCIB 11029) \\
\hline Corynebacterium & 1 & C129(NCIB 9661) & luteum & & \\
\hline acetoacidophilum & & & Kurthia zopfii & 6 & $\mathrm{c} 37, \mathrm{c} 38, \mathrm{c} 72, \mathrm{c} 77$ (D. \\
\hline C. aquaticum & 1 & ${ }^{*} \mathrm{C} 84$ (NCIB 9460) & & & Jones; c5, c6, c7, c20 \\
\hline C. autotrophicum & 5 & $\begin{array}{l}\mathrm{C} 182 \text { to } \mathrm{C} 185(\mathrm{H} . \mathrm{C} \text {. } \\
\text { Schlegel; 7C mut, } 7 \mathrm{CWA} \text {, }\end{array}$ & & & $\begin{array}{l}\left.{ }^{*} \text { C } 45 \text { (NCTC } 404\right) ; \text { C187 } \\
\quad(\text { NCIB } 11555)\end{array}$ \\
\hline & & $\begin{array}{l}14 \mathrm{~g}, 301 \mathrm{~b}) ; \mathrm{Cl} 89(\mathrm{NClB} \\
10809)\end{array}$ & $\begin{array}{l}\text { Microbacterium } \\
\text { ammoniaphilum }\end{array}$ & 1 & Cl39 (NCIB 10335) \\
\hline C. betae & 2 & $\mathrm{C} 3, \mathrm{C} 258(\mathrm{NCPPB} 363,364)$ & Microbacterium & 1 & *D4 (NCIB 8707) \\
\hline C. bovis & 8 & C95, C97 (NIRD 1689, & flavum & & \\
\hline & & $\begin{array}{l}\text { 1928); C98 to C103 } \\
\text { (J. E. Shreeve, Central }\end{array}$ & $\begin{array}{l}\text { Microbacterium } \\
\text { lacticum }\end{array}$ & 1 & $\begin{array}{l}\text { C91, C138 (NCIB } 8541 \text {, } \\
9919)\end{array}$ \\
\hline & & $\begin{array}{l}\text { Veterinary Laboratory, } \\
\text { Weybridge, Surrey; }\end{array}$ & $\begin{array}{l}\text { Mycobacterium } \\
\text { flavum }\end{array}$ & 1 & D5 (NCIB 10071) \\
\hline & & DB $223 / 75$, DB132/75, & Mycoplana rubra & 1 & C224 (NCIB 10409) \\
\hline & & DB2 $10 / 75$, DB $30 / 75$, & Nocardia cellulans & & N40 (NCIB 8868) \\
\hline & & $\mathrm{DB} 94 / 75,120 \mathrm{~B})$ & Oerskovia & 1 & ${ }^{*} \mathrm{C} 252(\mathrm{NCIB} 11025)$ \\
\hline C. callunae & 1 & $\mathrm{Cl} 30(\mathrm{NCIB} 10338)$ & xanthineolytica & & \\
\hline C. diphtheriae & 1 & C13 (NCTC 3985) & Protaminobacter ruber & 1 & $\mathrm{C} 251$ (NCIB 2879) \\
\hline C. equi & 8 & $\begin{array}{l}\text { C56 to C58 (NCTC } 5649, \\
5650,4219) ; \text { D } 19 \text { to D } 23 \\
\text { (H. R. Carne, Cambridge } \\
\text { University; 20343, } \\
\text { Jeffcott 1, 149, 1499, } \\
\text { Jeffcott 11) }\end{array}$ & & & \\
\hline
\end{tabular}

* Type strain.

$\uparrow$ ATCC, American Type Culture Collection; DSM, Deutsche Sammlung für Mikroorganismen; NCIB, National Collection of Industrial Bacteria; NCPPB, National Collection of Plant Pathogenic Bacteria; NCTC, National Collection of Type Cultures; NIRD, National Institute for Research in Dairying, Shinfield, Reading; C, D, H, N, laboratory numbers. 
Table 2. Peaks corresponding to molecular ions in the mass spectra of menaquinones from organisms having dihydrogenated menaquinone main components with eight isoprene units

The main component in each series is denoted by +++ , any components greater than $50 \%$ of the main peak by ++ , and all other significant components by + .

\begin{tabular}{|c|c|c|c|c|c|c|c|}
\hline \multirow{2}{*}{$\begin{array}{c}\text { Menaquinone isoprenologue } \\
\text { Degree of hydrogenation } \\
m / e\end{array}$} & & \multirow{2}{*}{$\begin{array}{l}\mathrm{MK}-7 \\
\left(\mathrm{H}_{2}\right) \\
650\end{array}$} & \multicolumn{3}{|c|}{ MK-8 } & \multicolumn{2}{|c|}{ MK-9 } \\
\hline & & & $\overline{716}$ & $\begin{array}{c}\left(\mathrm{H}_{2}\right) \\
718\end{array}$ & $\begin{array}{c}\left(\mathrm{H}_{4}\right) \\
720\end{array}$ & $\overline{784}$ & $\begin{array}{c}\left(\mathbf{H}_{2}\right) \\
786\end{array}$ \\
\hline Arthrobacter roseoparaffinus & $\mathrm{C} 112$ & + & + & +++ & - & - & - \\
\hline Brevibacterium linens & $\mathrm{c} 83$ & + & + & $+t+$ & - & - & - \\
\hline B. paraffinolyticum & $\mathrm{C} 113$ & + & + & +++ & - & - & - \\
\hline B. stationis & $\mathrm{c} 41$ & + & + & +++ & - & + & ++ \\
\hline B. sterolicum & $\mathrm{c} 188$ & + & + & +++ & - & - & - \\
\hline Corynebacterium diphtheriae & $\mathrm{C} 13$ & + & + & $++t$ & - & - & - \\
\hline C. equi & $\mathrm{c} 56$ & + & + & ++ & - & - & + \\
\hline & C57 & + & + & +++ & - & - & + \\
\hline & c58 & + & + & $++t$ & - & - & - \\
\hline & D19 & + & + & +++ & - & - & - \\
\hline & $\mathrm{D} 20$ & + & + & +++ & - & - & - \\
\hline & $\mathrm{D} 21$ & + & + & +++ & - & - & - \\
\hline & $\mathrm{D} 22$ & + & + & $++t$ & - & - & - \\
\hline & D23 & + & + & +++ & - & - & - \\
\hline C. fascians & c104 & + & + & +++ & - & - & - \\
\hline C. hoagii & $\mathrm{C} 24$ & + & + & $++t$ & - & - & - \\
\hline C. hydrocarboclastus & D8 & + & + & $+t+$ & - & - & - \\
\hline & D9 & + & + & $+t+$ & - & 一 & - \\
\hline C. minutissimum & D24 & + & + & +++ & - & + & ++ \\
\hline C. murium & $\mathrm{c} 60$ & + & + & +++ & - & - & - \\
\hline C. mycetoides & $\mathrm{c} 63^{*}$ & + & + & +++ & - & + & $+t$ \\
\hline C. pseudodiphtheriticum & $\mathrm{C} 19$ & + & + & +++ & - & - & - \\
\hline C. renale & $\mathbf{H} 1$ & + & + & +++ & + & - & - \\
\hline & $\mathrm{H} 2$ & + & + & +++ & + & - & + \\
\hline & H4 & + & + & +++ & + & - & - \\
\hline C. rubrum & $\mathrm{C} 190$ & + & + & +++ & + & - & - \\
\hline C. xerosis & $\mathrm{c} 137$ & + & + & +++ & - & - & + \\
\hline Microbacterium flavum & D4 & + & + & +++ & - & - & + \\
\hline
\end{tabular}

* Significant amounts of $\mathrm{MK}-10\left(\mathrm{H}_{2}\right)(m / e$ 854) were also detected.

\section{RESULTS}

Extracts of the test strains contained either menaquinones or ubiquinones which cochromatographed with standards of vitamin K and ubiquinone-9, respectively. Menaquinones were detected in 85 strains and ubiquinones in the remaining 10 . The most intense peaks in the mass spectra of menaquinones occurred at $\mathrm{m} / \mathrm{e} 187$ and 225 and were derived from the naphthoquinone nucleus. The ubiquinones produced base peaks at $m / e 235$, derived from the benzoquinone nucleus, and intense peaks at $m / e 197$. The mass spectra in the high mass region contained strong peaks corresponding to molecular ions $\left(\mathrm{M}^{+}\right)$with smaller peaks at $\mathrm{M}^{+}-15$ corresponding to the loss of a methyl group from the molecular ion. Details of the mass spectral analyses are shown in Tables 2 to 6.

Corynebacteria from animal sources, and strains labelled Arthrobacter roseoparaffinus, Brevibacterium linens, Brevibacterium paraffinolyticum, Brevibacterium sterolicum, Corynebacterium fascians, Corynebacterium hydrocarboclastus, Corynebacterium rubrum and Microbacterium flavum contained, as major components, menaquinones having eight isoprene units with one double-bond hydrogenated (Table 2). In contrast, the saprophytic corynebacteria, Microbacterium ammoniaphilum and variously labelled Arthrobacter and Brevibacterium strains possessed dihydromenaquinones with nine isoprene units as major components (Table 3). The single representatives of Arthrobacter variabilis and Brevibacterium stationis contained comparable amounts of $\mathrm{MK}-8\left(\mathrm{H}_{2}\right)$ and $\mathrm{MK}-9\left(\mathrm{H}_{2}\right)($ Tables 2,3$)$. 
Table 3. Peaks corresponding to molecular ions in the mass spectra of menaquinones from organisms having dihydrogenated menaquinone main components with nine isoprene units

The main component in each series is denoted by +++ , any components greater than $50 \%$ of the main peak by ++ , and all other significant components by + .

Menaquinone isoprenologue

Degree of hydrogenation $m / e$

Arthrobacter albidus

A. crystallopoietes

A. globiformis

A. polychromogenes

A. ureafaciens

A. variabilis

Brevibacterium ammoniagenes

$B$. divaricatum

B. flavum

B. immariophilum

B. lactofermentum

B. roseum

B. saccharolyticum

Corynebacterium

acetoacidophilum

C. bovis

$\begin{array}{ll}\text { C. bovis } & \mathrm{C} 95 \\ & \mathrm{C} 97 \\ & \mathrm{c} 98 \\ & \mathrm{c} 99 \\ & \mathrm{c} 100 \\ & \mathrm{c} 101 \\ & \mathrm{c} 102 \\ & \mathrm{c} 103 \\ \text { C. callunae } & \mathrm{c} 130 \\ \text { C. herculis } & \mathrm{c} 85 \\ \text { C. lilium } & \mathrm{c} 133 \\ \text { C. melassecola } & \mathrm{C} 136 \\ \text { Microbacterium } & \mathrm{c} 139 \\ \text { ammoniaphilum } & \end{array}$

MK-7

MK-8

$\left(\mathrm{H}_{2}\right)$

$\left(\mathrm{H}_{2}\right)$

650

D6

C218*

N549*

C219

C220

$\mathrm{D} 2$

C80

D3

C81

$\mathrm{c} 123$

C124

C82

C127

c129

C95

C97

c99

100

C102

103

$\mathrm{C} 85$

136

C139
718

+
+
+
+
+
++
+
+
+
+
+
+
+
+

$+$

$+$

$+$

$+$

$+$

+
+

$+$

$+$

$+$

+
+
MK-9

$\overbrace{784}^{\left(\mathrm{H}_{2}\right)}$

$+\quad+++$

$+\quad++$

$+\quad+++$

$+\quad+++$

$+\quad+++$

$+\quad+++$

$+\quad+++$

$+\quad+++$

$+\quad+++$

$+\quad+++$

$+\quad+++$

$+\quad+++$

$+\quad+++$

$+\quad+++$

$+\quad++$

$+\quad+++$

$+\quad+++$

$+\quad+++$

$+\quad++$

$+\quad+++$

$+\quad+++$

$+\quad+++$

$+\quad+++$

$+\quad+++$

$+\quad+++$

$\begin{array}{lll}+ & +++ \\ + & ++\end{array}$

* Significant amounts of MK- $10\left(\mathrm{H}_{2}\right)(\mathrm{m} / \mathrm{e}$ 854) were also detected.

Table 4. Peaks corresponding to molecular ions in the mass spectra of menaquinones from organisms having tetrahydrogenated menaquinone main components

The main component in each series is denoted by +++ , any components greater than $50 \%$ of the main peak by ++ , and all other significant components by + .

Menaquinone isoprenologue

Degree of hydrogenation

$$
m / e
$$

Arthrobacter simplex

A. tumescens

Brevibacterium fermentans

Cellulomonas biazotea

Cell. cartalyticum

Cell. fimi

Cell. flavigena

Cell. subalbus

Corynebacterium manihot

Nocardia cellulans

Oerskovia xanthineolytica
MK-7

$\mathrm{C} 272$

$\mathrm{C} 273$

C122

$\mathrm{C} 221$

C266

c274

C111

C222

$\mathrm{C} 134$

$\mathrm{N} 40$

C252

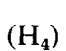

652

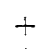

$+$

$+$

$+$

$+$

$+$

$+$

$+$

+
+
+

$\overbrace{\substack{\left(\mathrm{H}_{2}\right) \\ 786}}^{\text {MK-9 }} \underbrace{\text {. }}_{\substack{\left(\mathrm{H}_{4}\right) \\ 788}}$

$\left(\mathrm{H}_{4}\right)$

720

$++$

$+t$

$+t$

$+$

$+$

$++$

$+$

$+$

+
+

$+$ $\begin{array}{cc}- & - \\ - & - \\ - & - \\ + & +++ \\ + & +++ \\ + & +++ \\ + & +++ \\ + & +++ \\ + & +++ \\ + & +++ \\ + & +++ \\ + & +++\end{array}$ 
Table 5. Peaks corresponding to molecular ions in the mass spectra of menaquinones from organisms having totally unsaturated menaquinone components

The main component in each series is denoted by +++ , any component greater than $50 \%$ of the main peak by ++ , and all other significant components by + .

\begin{tabular}{|c|c|c|c|c|c|c|c|c|c|}
\hline $\begin{array}{l}\text { Menaquinone } \\
\text { isoprenologue }\end{array}$ & & MK-6 & & & MK-8 & MK-9 & $\mathrm{MK}-10$ & $\mathrm{MK}-11$ & MK- 12 \\
\hline Degree of hydrogenation & & - & - & $\left(\mathrm{H}_{2}\right)$ & 一 & $\ldots$ & - & — & $\ldots$ \\
\hline$m / e$ & & 580 & 648 & 650 & 716 & 784 & 852 & 920 & 988 \\
\hline $\begin{array}{l}\text { Brevibacterium } \\
\text { sulfureum }\end{array}$ & c79 & - & + & - & + & +++ & + & - & - \\
\hline $\begin{array}{l}\text { Corynebacterium } \\
\text { aquaticum }\end{array}$ & C84 & - & - & - & + & + & $++^{*}$ & $++t$ & + \\
\hline C. betae & C3 & - & + & - & + & +++ & + & - & - \\
\hline & $\mathrm{c} 258$ & - & + & - & + & +++ & - & - & - \\
\hline C. Alaccumfaciens & C9 & - & + & - & + & +++ & - & - & - \\
\hline C. nebraskense & H11 & - & + & - & + & +++ & + & - & - \\
\hline & H12 & - & + & - & + & $+t+$ & + & - & - \\
\hline C. poinsettiae & c1l & - & + & - & + & $+t+$ & - & - & - \\
\hline $\begin{array}{l}\text { Curtobacterium } \\
\text { citreum }\end{array}$ & C93 & - & + & - & + & +++ & - & - & - \\
\hline Curtobacterium luteum & C94 & - & + & - & + & +++ & - & - & - \\
\hline Kurthia zopfii & c37 & + & +++ & - & - & - & - & - & - \\
\hline & C38 & + & +++ & - & - & - & - & 一 & - \\
\hline & $\mathrm{C} 45$ & + & +++ & - & - & - & - & - & - \\
\hline & C72 & + & $++t$ & - & 一 & 一 & - & $\rightarrow$ & - \\
\hline & $\mathrm{C} 77$ & + & +++ & ++ & - & - & - & - & - \\
\hline & $\mathrm{c} 187$ & + & +++ & - & - & - & - & - & - \\
\hline Microbacterium & C91 & - & - & - & + & + & $++*$ & $++t$ & + \\
\hline lacticum & C138 & - & - & - & + & + & $+t^{*}$ & $+t+$ & + \\
\hline
\end{tabular}

* Intensity very similar to that of main peak.

Tetrahydrogenated menaquinones with eight isoprene units were found in Arthrobacter simplex and Arthrobacter tumescens (Table 4) whereas $\mathrm{MK}-9\left(\mathrm{H}_{4}\right)$ was the predominant isoprenologue in Brevibacterium fermentans, Corynebacterium manihot, Nocardia cellulans, Oerskovia xanthineolytica and Cellulomonas strains (Table 4).

Kurthia zopfii strains contained MK-7 as the major isoprenologue with smaller quantities of MK-6 (Table 5). Curtobacterium citreum and Curtobacterium luteum possessed MK-9 as the major component, and essentially similar patterns were found in strains labelled Brevibacterium sulfureum, Corynebacterium betae, Corynebacterium flaccumfaciens, Corynebacterium nebraskense and Corynebacterium poinsettiae (Table 5). The mass spectra of the menaquinones from Corynebacterium aquaticum and Microbacterium lacticum are characteristic since they contain peaks of comparable intensity at $m / e 852$ and 920 , corresponding to $\mathrm{MK}-10$ and MK- 11 , respectively, and smaller peaks at $m / e 716,784$ and 988 corresponding to the minor components MK- 8 , MK-9 and MK-12, respectively (Table 5).

The Corynebacterium autotrophicum, Corynebacterium nephridii, Mycoplana rubra and Protaminobacter ruber strains possessed ubiquinones as the sole isoprenoid quinones with Q-10 and Q- $10\left(\mathrm{H}_{2}\right)$ predominating (Table 6). The single strains of Brevibacterium leucinophagum and Mycobacterium flavum contained Q-9 and Q-10, respectively, as the major isoprenologues. 
Table 6. Peaks corresponding to molecular ions in the mass spectra of ubiquinones from organisms having ubiquinones as sole isoprenoid quinone components

The main component in each series is denoted by +++ , any components greater than $50 \%$ of the main peak by ++ , and all other significant components by + .

Ubiquinone isoprenologue

Degree of hydrogenation $m / e$

Brevibacterium leucinophagum Corynebacterium autotrophicum

C. nephridii

Mycobacterium flavum

Mycoplana rubra

Protaminobacter ruber

\begin{tabular}{|c|c|c|c|}
\hline \multicolumn{2}{|c|}{ Q-8 } & \multicolumn{2}{|c|}{ Q-9 } \\
\hline- & $\left(\mathrm{H}_{2}\right)$ & - & $\left(\mathrm{H}_{2}\right)$ \\
\hline 726 & 728 & 794 & 796 \\
\hline+ & - & +++ & - \\
\hline- & - & + & + \\
\hline- & - & + & + \\
\hline - & - & + & + \\
\hline- & - & + & + \\
\hline - & - & + & + \\
\hline+ & + & + & + \\
\hline - & - & + & + \\
\hline - & - & + & + \\
\hline+ & + & + & + \\
\hline
\end{tabular}

* Intensity very similar to that of main peak.

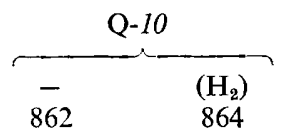

$-$

$++$

$++$

$+t^{*}$

$++*$

$++$

$+t$

$+t$

$+t^{*}$

$++*$

(2)

$+\overline{+}+$

$+t$

$+t$

$+t$

$+t$

$++*$

$+$

$+t$

$++$

\section{DISCUSSION}

The strong chemical case for restricting the genus Corynebacterium to the human and animal strains and related saprophytic bacteria (Schleifer \& Kandler, 1972; Goodfellow et al., 1976; Keddie \& Cure, 1977) is supported by data derived from the application of other taxonomic methods (Barksdale, 1970; Bousfield, 1972; Jones, 1975). Considering chemical characters only, Corynebacterium sensu stricto can be restricted to those bacteria having a wall chemotype IV, a DNA base composition in the range 48 to $59 \mathrm{~mol} \% \mathrm{G}+\mathrm{C}$ and relatively low molecular weight mycolic acids (20 to 38 carbon atoms) (Keddie, 1976, 1978; Keddie \& Cure, 1977, 1978; Minnikin et al., 1978).

The true corynebacteria can be divided into two groups on the basis of menaquinone composition. Thus, the human and animal pathogens and related strains possess $\mathrm{MK}-8\left(\mathrm{H}_{2}\right)$ as the major isoprenologue whereas Corynebacterium bovis and Corynebacterium glutamicum contain MK-9 $\left(\mathrm{H}_{2}\right)$ (Collins et al., 1977). The glutamic acid-producing strains Arthrobacter albidus, Brevibacterium ammoniagenes, B. divaricatum, B. flavum, B. immariophilum, B. lactofermentum, B. roseum, B. saccharolyticum, Corynebacterium callunae, C. herculis and $C$. lilium also contain $\mathrm{MK}-9\left(\mathrm{H}_{2}\right)$ as the major component, have a wall type IV and, where tested, contain mycolic acids similar to those of true corynebacteria (Goodfellow et al., 1976; Keddie \& Cure, 1977). All of these strains should be transferred to the genus Corynebacterium sensu stricto (Barksdale, 1970; Minnikin et al., 1978). Corynebacterium melassecola and Microbacterium ammoniaphilum also contain predominant amounts of MK- $9\left(\mathrm{H}_{2}\right)$ and so may belong to Corynebacterium sensu stricto, although further studies are required to confirm this. The menaquinone data do not contradict the view that many of the glutamic acid-producing nomenspecies should be reduced to synonymy with $C$. glutamicum (Abe et al., 1967; Bousfield \& Goodfellow, 1976).

The classification of strains labelled Corynebacterium equi, C. fascians, C. hydrocarboclastus and C. rubrum in the genus Rhodococcus (Goodfellow \& Alderson, 1977) is not contradicted by the menaquinone data. The type strain of Brevibacterium linens also possesses $\mathrm{MK}-8\left(\mathrm{H}_{2}\right)$ as the major isoprenologue but, unlike the animal pathogenic corynebacteria and rhodococci, it does not contain mycolic acids (Goodfellow et al., 1976). Strains labelled Arthrobacter roseoparaffinus, Brevibacterium paraffinolyticum and B. sterolicum contain major amounts of $\mathrm{MK}-8\left(\mathrm{H}_{2}\right)$. Further studies are required to determine whether these taxa should be transferred to the genus Corynebacterium or to Rhodococcus. 
The genus Arthrobacter is heterogeneous, and Arthrobacter globiformis and related strains can readily be distinguished from A. simplex and A. tumescens (Schleifer \& Kandler, 1972; Keddie, 1974; Keddie \& Cure, 1977). The menaquinone results underline this division since A. globiformis, A. crystallopoietes, A. polychromogenes and A. ureafaciens contain predominant amounts of MK- $9\left(\mathrm{H}_{2}\right)$ (Table 3 ) whereas $A$. simplex and $A$. tumescens possess major quantities of $\mathrm{MK}-8\left(\mathrm{H}_{4}\right)$ (Table 4) as do nocardiae (Yamada et al., 1976). However, unlike nocardiae, these arthrobacters do not contain MK-6 $\left(\mathrm{H}_{4}\right)($ Collins et al., 1977). Our data cast doubt upon the report that $A$. crystallopoietes contains a ubiquinone (Kostiw et al., 1972).

The integrity of the genus Curtobacterium is supported by the menaquinone data, for the curtobacteria, Corynebacterium flaccumfaciens and Corynebacterium poinsettiae contain MK-9 as the major isoprenologue. Further systematic work needs to be carried out on Curtobacterium (Brevibacterium) testaceum which has been reported to contain MK-II (Yamada et al., 1976). The Brevibacterium sulfureum and Corynebacterium nebraskense strains also contain menaquinones with nine isoprene units and should be compared further with curtobacteria. It has been suggested that $B$. sulfureum should be transferred to the genus Arthrobacter (Yamada \& Komagata, 1972) and there is a good deal of evidence to support this (Yamada \& Komagata, 1970b; Schleifer \& Kandler, 1972; Keddie \& Cure, 1977,1978 ). However, the menaquinone data are at variance with the proposal to reclassify B. sulfureum in Arthrobacter and additional strains of this taxon need to be compared with arthrobacters and curtobacteria.

The present study (Table 4) confirms that MK-9 $\left(\mathrm{H}_{4}\right)$ is the major isoprenologue of cellulomonads and oerskoviae (Collins et al., 1977; Yamada et al., 1976) but the walls of representatives examined contain ornithine and lysine, respectively (Prauser et al., 1970; Keddie \& Cure, 1977). Brevibacterium fermentans, Corynebacterium manihot and Nocardia cellulans also contain major amounts of $\mathrm{MK}-9\left(\mathrm{H}_{4}\right)$ and all three have been found to contain lysine in their walls (Keddie \& Cure, 1977; I. J. Bousfield, personal communication) suggesting a close affinity with Oerskovia.

Kurthia zopfii strains contain MK-7 as the predominant component and can thereby be distinguished from all coryneform and actinomycete strains examined to date (Collins et al., 1977; Yamada et al., 1976). Kurthiae can also be distinguished from the coryneforms by their morphology (Keddie \& Rogosa, 1974) and low GC content (L. R. Hill, personal communication), and they have been recovered as a distinct homogeneous phenon in numerical phenetic surveys (Jones, 1975; Wilkinson \& Jones, 1977).

The Corynebacterium aquaticum and Microbacterium lacticum strains also had an unusual menaquinone composition consisting of comparable amounts of MK-10 and MK-11 as the major isoprenologues. However, $C$. aquaticum can readily be distinguished from $M$. lacticum, because the former contains D-diaminobutyric acid as the major diamino acid of the peptidoglycan whereas the latter possesses L-lysine (Schleifer \& Kandler, 1972).

The recovery of ubiquinones from Brevibacterium leucinophagum, Corynebacterium autotrophicum, Corynebacterium nephridii, Mycobacterium flavum, Mycoplana rubra and Protaminobacter ruber indicates that the classification of these taxa requires further study. Ubiquinones are common in Gram-negative bacteria (Thomson, 1971) but are rare in coryneform bacteria (Minnikin et al., 1978). Jones \& Weitzman (1974) found that Brevibacterium leucinophagum was Gram-negative and proposed its transfer to the genus Acinetobacter. The recovery of major amounts of ubiquinones with nine isoprene units from B. leucinophagum supports this assignment, as Acinetobacter strains also possess Q-9 as their major isoprenologue (Makula et al., 1975).

The results of the present study confirm and extend earlier work (Yamada et al., 1976; Collins et al., 1977) which showed the value of isoprenoid quinone analyses in the classification of coryneform and related taxa, but further studies are necessary to evaluate the full potential of such analyses. 
We are indebted to colleagues who kindly provided cultures (Table 1) and to P. Kelly for mass spectroscopy. M.D.C. gratefully acknowledges receipt of a Luccock Scholarship (Medical Scholarships and Research Committee, Faculty of Medicine, University of Newcastle upon Tyne).

\section{REFERENCES}

Abe, S., Takayama, K. \& Kinoshita, S. (1967). Taxonomical studies on glutamic acid-producing bacteria. Journal of General and Applied Microbiology 13, 279-301.

allen, C. F., Franke, H. \& Hirayama, O. (1967). Identification of a plastoquinone and two naphthoquinones in Anacystis nidulans by n.m.r. and mass spectroscopy. Biochemical and Biophysical Research Communications 26, 562-568.

Alshamaony, L., Goodfellow, M., Minnikin, D. E. \& Mordarska, H. (1976). Free mycolic acids as criteria in the classification of Gordona and the 'rhodochrous' complex. Journal of General Microbiology 92, 183-187.

BARKSDALE, L. (1970). Corynebacterium diphtheriae and its relatives. Bacteriological Reviews 34, 378422.

Beau, S., Azerad, R. \& Lederer, E. (1966). Isolément et caractérisation des hydro-menaquinones des myco- et corynébactéries. Bulletin de la Société de chimie biologique 48, 569-581.

Bousfield, I. J. (1972). A taxonomic study of some coryneform bacteria. Journal of General Microbiology 71, 441-455.

Bousfield, I. J. \& Goodfellow, M. (1976). The 'rhodochrous' complex and its relationships with allied taxa. In The Biology of the Nocardiae, pp. 39-65. Edited by M. Goodfellow, G. H. Brownell \& J. A. Serrano. London: Academic Press.

Bowie, I. S., Grigor, M. R., Dunckley, G. G., Loutit, N. W. \& LouTiT, J. S. (1972). The DNA base composition and fatty acid constitution of some Gram-positive pleomorphic soil bacteria. Soil Biology and Biochemistry 4, 397-412.

Collins, M. D., Pirouz, T., Goodfellow, M. \& Minnikin, D. E. (1977). Distribution of menaquinones in actinomycetes and related bacteria. Journal of General Microbiology 100, 221-230.

Cowan, S. T. (1974). Manual for the Identification of Medical Bacteria, 2nd edn. Cambridge: Cambridge University Press.

Crombach, W. H. J. (1972). DNA base composition of soil arthrobacters and other coryneforms from cheese and sea fish. Antonie van Leeuwenhoek 38, $105-120$.

Frits, P., Daves, G. D. \& Folkers, K. (1967). New epoxyubiquinones. Biochemistry 6, 3618-3624.

Goodfellow, M. \& Alderson, G. (1977). The actinomycete-genus Rhodococcus: a home for the 'rhodochrous' complex. Journal of General Microbiology 100, 99-122.

Goodfellow, M., Collins, M. D. \& Minnikin, D. E. (1976). Thin-layer chromatographic analysis of mycolic acid and other long-chain components in whole-organism methanolysates of coryneform and related taxa. Journal of General Microbiology 96, 351-358.

JoNES, D. (1975). A numerical study of coryneform and related bacteria. Journal of General Microbiology 87, 52--96.

Jones, D. \& Weitzman, P. D. J. (1974). Reclassification of Brevibacterium leucinophagum Kinney and Werkman as a Gram-negative organism, probably in the genus Acinetobacter. International Journal of Systematic Bacteriology 24, 113-117.

KedDie, R. M. (1974). Genus Arthrobacter. In Bergey's Manual of Determinative Bacteriology, 8 th edn. Edited by R. E. Buchanan \& N.E. Gibbons. Baltimore: Williams \& Wilkins.

KEDDIE, R. M. (1976). What do we mean by coryneform bacteria? Proceedings of the Society for General Microbiology 3, 96-97.

KedDiE, R. M. (1978). What do we mean by coryneform bacteria? In Coryneform Bacteria, pp. 1-12. Edited by I. J. Bousfield \& A. G. Callely. London: Academic Press.

Keddie, R. M. \& Cure, H. L. (1977). The cell wall composition and distribution of free mycolic acids in named strains of coryneform bacteria and in isolates from various natural sources. Journal of Applied Bacteriology 42, 229-252.

Keddie, R. M. \& Cure, G. L. (1978). Cell wall composition of coryneform bacteria. In Coryneform Bacteria, pp. 47-84. Edited by I. J. Bousfield \& A. G. Callely. London: Academic Press.

Keddie, R. M. \& Rogosa, M. (1974). Genus Kurthia. In Bergey's Manual of Determinative Bacteriology, 8th edn. Fdited by R. E. Buchanan \& N. E. Gibbons. Baltimore: Williams \& Wilkins. Keddie, R. M., Leask, B. G. S. \& Grainger, J. M. (1966). A comparison of coryneform bacteria from soil and herbage: cell wall composition and nutrition. Journal of Applied Bacteriology 29, 17-43.

Kostiw, L. L., Boylen, C. W. \& Tyson, B. J. (1972). Lipid composition of growing and starving cells of Arthrobacter crystallopoietes. Journal of Bacteriology 111, 103-111.

Makula, R. A., Lockwood, P. J. \& Finnerty, W. R. (1975). Comparative analysis of the lipids of Acinetobacter species grown on hexadecane. Journal of Bacteriology 121, 250-258.

Minnikin, D. E., Goodfellow, M. \& Collins, M. D. (1978). Lipid composition in the classification and identification of coryneform and related taxa. In Coryneform Bacteria, pp. 85-160. Edited by I. J. Bousfield \& A. G. Callely. London: Academic Press.

Prauser, H., Lechevalier, M. P. \& Lechavalier, H. (1970). Description of Oerskovia gen.n. to harbor Ørskov's motile Nocardia. Applied Microbiology 19, 534.

Rogosa, M., Cummins, C. S., Lelliott, R. A. \& KeDdIE, R. M. (1974). Coryneform group of bacteria. In Bergey's Manual of Determinative Bacteriology, 8th edn. Edited by R. E. Buchanan \& N. E. Gibbons. Baltimore: Williams \& Wilkins. 
Schleifer, K. H. \& Kandler, O. (1972). Peptidoglycan types of bacterial cell walls and their taxonomic implication. Bacteriological Reviews 36, 407-477.

Schwartz, A. C. (1973). Terpenoid quinones of the anaerobic Propionibacterium shermanii. Archiv für Mikrobiologie 91, 273-279.

Skyring, G. W. \& QuAdLing, C. (1970). Soil bacteria: a principal component analysis and guaninecytosine contents of some arthrobacter-coryneform soil isolates and some named cultures. Canadian Journal of Microbiology 16, 95-106.

SoNE, N. (1974). Isolation of a novel menaquinone with a partly hydrogenated side chain from Propionibacterium arabinosum. Journal of Biochemistry 76, 133-136.

Starr, M. P., Mandel, M. \& Murata, M. (1975). The phytopathogenic coryneform bacteria in the light of DNA base composition and DNA-DNA segmental homology. Journal of General and Applied Microbiology 21, 13-26.

THOMSON, R. H. (1971). Naturally Occurring Quinones. London: Academic Press.
Wilkinson, B. J. \& Jones, D. (1977). A numerical taxonomic survey of Listeria and related bacteria. Journal of General Microbiology 98, 399-421.

Yamada, K. \& Komagata, K. (1970a). Taxonomic studies on coryneform bacteria. II. Principal amino acids in the cell wall and their taxonomic significance. Journal of General and Applied Microbiology 16, 103-113.

Yamada, K. \& Komagata, K. (1970b). Taxonomic studies on coryneform bacteria. III. DNA base composition of coryneform bacteria. Journal of General and Applied Microbiology 16, 215-224.

Yamada, K. \& Komagata, K. (1972). Taxonomic studies on coryneform bacteria. V. Classification of coryneform bacteria. Journal of General and Applied Microbiology 18, 417-431.

Yamada, Y., Inouye, G., Tahara, Y. \& Kondo, K. (1976). The menaquinone system in the classification of coryneform and nocardioform bacteria and related organisms. Journal of General and Applied Microbiology 22, 203-214. 